\title{
Conflict Management on Group Religious in Islam (Case Studies in Empowerment of Group Religious in Banyumas District):
}

\author{
Abdul Rohman, Elis Puspitasari \\ Faculty of Social and Political Sciences \\ (rohman_mudis@yahoo.com)
}

\begin{abstract}
This study entitled “Conflict Management among Islamic Religious Groups”. The objectives of this study are: to know the causes of conflict among Muslims groups; and to manage effectively conflict between religious groups. To manage confict among muslims community needs consideration, that are :1) All of Islamic groups always handled tolerance values, but they don't communicate with else or have differ interpretation or no media as mediator. 2) The concept of tolerance forward as not aqidah, but only mu'ammalah problems or human relations and say as issues of fiqh ; 3) The development of information technology (IT) as a result of human thinking which can be used as a tools of Islamic Social Networking to create intellectual friendship, so can grows values of tolerance, democracy and moderation.

Based on some potential of conflicts, I wish conflicts among Muslims more easely to manage so can became as strong references to create peace in life together. So the most importantthing requiredisthe existence of amediumused forcommunicationbetween them.
\end{abstract}

Keywords : management, Islamic teaching, religious groups, information technology

\section{Background}

Observing the phenomenon of state-Muslimmajority countries inthe world to day really very sad. The suicide bombing, the conflict fellow citizens, mutual suspicion and destroy surrounding their lives. The resurrection of the Arab world against the tyran nical despotism systems since 2010 ago, is still far from stable. Iraq, Syria, and Egyptis not the earth a safe and pleasant place to live (Ma'arif, 2013).

The existence of Muslims in the world in general has the same character. Democracy in religion is an undeniable characteristic of the Islamic society. The differences in point of view of religious teachings are very easily found in different parts of the world. Truth claims individually and collectively in the interpretation of religion is also often encountered. Due to the presence of people like that, often horizontal conflicts among them. If this is the case in Indonesia, not only Muslims destroyed, but this nation will be destroyed. Because the Indonesian Muslim were majority nation.
Islam is the last religion that brings rahmatan lil'alamin mission, should give you a feel of peace and coolness for all adherents and its environment. However, when reduced by the dominant interpretation of the doctrine of shariah by the flow of the group, especially when faced with a difference of interpretation, making the religious attitude of the congregation group is very limited, especially when interacting with other religious sects. But when they interact with their own group they are very familiar. This is illustrated by the results of studies that have been done Rohman (2008) about Perception Group of Syahadatain on Social Interaction and Religious showing that interaction can be done with his own group are good, but when interacting with other groups is very limited. Then in the next study, Rohman (2009) on the perception of Islam Jama'ah group on Religious and Social Interaction, also get the same data of group Syahadatain.

Such circumstances it would be even more complicated when coupled with the existence of 
religious beliefs, which is more aggressive and political, such as HTI group. Dahlan study result (2008) was said that HTI is an organization that wants to build daulah fighting Islamic caliphate based on Islamic law. This movement is not only contrary to the government of Indonesia has set Indonesia as a democratic state based on Pancasila and the 1945 Constitution, but also can intersect with other religious sects that have received final in Indonesia as a democratic state.

In the magazine of Majemuk notes (2008), that during the year 2007 and has been a breach of freedom of religion and belief reaches 135 cases. This means that the feel of friction and conflict in society really become a serious issue that must be considered by all parties, especially the search for preventive measures so as little as possible to prevent its appearance at a later date.

Differences of interpretation, such as the attitude and movement can trigger the growth of intolerant attitudes in social and religious life in society. Even the social conflicts that often happens too much due to differences in the interpretation of religion. One example of social conflict is the ever tumultuous riot Situbondo 1996. According to Darto Harnoko (201), that the riots were caused by the primordial attitude that emphasizes group alone, so tend to think outside of their group is an enemy that must always be aware ofits existence.

Based on the descriptionof thebackground, the formulation ofthe problem raisedishow tomanage the conflicts that often occur in groups of Muslims?

\section{Methods study}

The methods usedinthisstudyis aqualitative method with the aim to describe and analyze the perceptions, views, attitudes, behaviors containedin the group Muhammadiyah, Nahdlatul Ulama(NU), Islamic Jama'ah or Indonesian Islamic Da'wah Institute (LDII), Syahadatain, Hizbut Tahrir Indonesia (HTI), Indonesian Islamic Da'wah Council (DDII), Salafi, AlErshadand Jama'at of Tabligh.

Then thedata collection was done through interviews were analyzed through interactive analysis echnique, which is implemented with the following steps:1) data reduction that researchers conduct the selection process, focusing, simplification, and abstraction of field-note. Then was made abbreviations, coding and memos, 2) data presentation to make the stories brief and systematic; and 3) conclusion.

\section{Analysis Study}

\subsection{Reducing the Causes of Conflict in the Islamic Group}

Nata (2001), said that any Islamic thought that there are 12 kinds of thought, each of which has its own characteristics and its own character. The twelve kinds are Islamic Fundamentalists, Islamic Theological - Normative Islam Exclusive, Rational Islam, Islam Transformative, Actual Islam, Islam Contextual, Esoteric Islam, Islam Traditionalist, Modernist Islam, Islamic Cultural and Inclusive Pluralist Islam. From the diversity of thought can be summed up into two separate ideas - or it could be the opposite -that the patterns of thought and patterns of thought traditionalists modernists. Any thoughts of all religious sects have their advantages and disadvantages value.

The problem that arises is when the interpretation of any religious beliefs, each claiming the right, but the results are conflicting interpretations and then cannot be compromised. Moreover, the 
interpretation of the results of recognition as a religious doctrine, and they feel guilty if not to implemented. These are religious interpretation that can foster horizontal conflict of religion in public life.So true what is said Jalaluddin Rahmat, in Jamil (2008) that religion is the fact the nearest and furthest mystery at the same time. So its approch, it is always present in our daily lives, whether at home, office, media, markets and anywhere. So mysterious, it often appeared faces that seem contradictory, the motivating force without compassion, devotion without limit, creating a mass movement of the most colossal and cried most heinous war.

Conditions such as these is a fact that occurred in Indonesia. Friction, offense, tension, violence, and conflict triggered by groups religious are commonsights. Even in view Azhari (2006) when looking atthe difference between Muhammadiyah and Nahdlatul Ulama (NU) in the current issue of reckoning and rukyat Qamariyah determine the beginning of the month, there are 4 models that are running, namely conflict, independence, dialogue and integration. When th integration modelis raised, not necessarilythe model characteristics and independence that ended the conflict. This means that in social life among a group with other groups remain nuance to the conflict, so we need an effective media. Although the actual Muhammadiyah and NU as religious organizations have co-existed for more than half a century.

Thus the need to be built in the Islamic group is the realization that we live in a pluralistic society, andhave an understanding of different religions. Therefore let's accept our differences, and differences in the community as a means flexibility to choose, because it's all still in the shade of Islam.

\subsection{Establish Tolerance in Religious Life Group}

When there is adifference in interpretation of religious beliefs, which are groups in society, then thebestwayto do is not a form always as a court, the hegemony of the ruling to eliminate its existence, but the path of negotiations, careful approach, and the development of tolerance values is much more elegant. Because conflict is only a difference of interpretation is essentially the interpretation of sacred texts, so that meanst he solution is also done in a way that is good and holy too.

Puspitasari (2011) states that the fundamental religious tolerance should always be planted, such as in a living state known as a consensus national unity unity of all ethnic groups, languages and religions that exist in Indonesia. Then Suwarno (2005) said, that is based on the analysis of the efforts for the resolution of religious conflicts in Indonesia, which is more suitable effort is an attempt to understand each other between groups of different religions. Then stressed that conflict resolution can be done through informal practices, such as friendship, deliberation and improvement.

If the return on the basis of the teachings of Islam that the Qur'an, it is clear that Islam is a religion of mercy that upholds justice, humanity and equality. There are no cultural barriers, social, ideological let alone that separates social interaction. Islam was dropped in Arab countries, but its mission remains universal. Locus Arabic, both the culture and the language is just as authentic evidence of the existence of Muslim descent, but the mission and the message still has a universal foundation that permeates the Arab geographical boundaries (Hidayat, 2003). This is confirmed by the Qur'an in Surat al -Anbiya: 107, which means : "And We 
have not to sent you, but to(be) a mercy tothe worlds".

Asa comprehensive religion and its applied until the end of time, so many verses that appear in general, especially in the Mu'amalat that are elasticadaptable. It can therefore be interpreted in accordance with the times. Then for every interpretationis affected by the presence of location, cultural and scientific background, then every interpreter allows to differ with an other interpreter, although the same verses.

This is evidenced in the history of Islam, in which the differences of interpretation is an amazing intellectual discourse. The emergence of the book Madzahibul Arba'ah (interpretation of religion by 4 interpretation, the Imam Hanafi, Maliki, Shafi'i and Hanbali) Abdurrahman al Jujairi work, is evidence of the existence of differences in the interpretation of religion and social issues. More beautiful, every mujtahid (one who did the interpretation) always said: If you consider my opinion correctly, please you take. But if you have another interpretation is more true, so take that interpretation. The statement signaled that the release will be relative interpretation.

Thusan understanding of the differences in interpretation of the verses of the Qur'an, should be recognized as a result of differences in viewpoint, social back ground, culture, politics, and the ability to understand theverse. These differences, if communicated, it would provide its own knowledge for each groups, which can cause awareness about the reality of differences, so that awareness of intellectual and rational tolerance can be realized by itself.

\subsection{Utilizing Information Technology}

Associated with the development of information technology (IT) that characterizes the various activities of human life, IT would be used as a means to assist in finding solutions. It's like I Putu Suhartika (2004) said, that was originally perceived information technology with various things such as a large and expensive, sophisticated or modern form (the elite) and the like. But with socialization and vigorous campaign then their perception ofITis increasingly clear. People are starting to recognize and use of IT -based tools, such as mobile phones, mobile remote, cable $\mathrm{TV}$, internet and so on. Symptoms such as these indicate awareness of the importance of ITin various aspects of life.

Looking at the fact that IT is so great benefit to human life, IT would also be used as a medium to develop the values of tolerance in religious sects in Islam through the Islamic Social Networking. Warsita (2007) stated that in the future the national, regional and global development and use of IT can act as a guide or a trendsetter. Then how to make it as a networking IT for the implementation and development of distance education in the future. This was confirmed by Pathmantara (2007), that the Internet can have a positive impact, ie access to resources; access to the resource; and as a medium for collaboration.

\section{Conclusion}

From the above it can be concluded :

1. The Life of heterogeneous society, so was needed the awareness among them about the existence of society is plural.

2. Islam is a universal religion, thus allowing interpretation between groups of people who differ from one another. It is therefore necessary 
to havean intellectual awareness among them, so that tolerance is built completely rational and responsible.

3. Existence of information technology (IT) can be used asa media strategy for managing conflict among Islamic groups, such as the Internet can be used as a medium of Islamic Social Networking, which aims to create an intellectual friendship, exchange opinions, deliberations and minimize flavor prejudice between groups.

\section{References}

(1) Abdurrahman, Moeslim. (1995). Islam Transformatif Jakarta: Pustaka Firdaus,

(2) Azhari, Susiknan. (2006). Karakteristik Hubungan Muhammadiyah dan NU dengan Menggunakan Hisab dan Rukyat.Al Jami'ah, Journal of Islamic Studies, 44 (2)

(3) Dahlan. (2008). Kelompok Kelompok Keagamaan Islam Transnasional Di Jawa Tengah, Jawa Timur Dan Daerah Istimewa Yogyakarta, Kasus Hizbut Tahrir Indonesia. Semarang: Balai Kajian Dan Pengembangan Agama

(4) Hidayat, Komarudin. (2003). Ketika Agama Menyejarah. Al Jami'ah, Journal of Islamic Studies, 40 (1)

(5) Harnoko, Darto. (2011). Kerusuhan Situbondo Oktober 1996.Jurnal Patrawidya, 12 (40)

(6) Jamil, Mukhsin. (2008). Agama Agama Baru Di Indonesia. Yogyakarta: Pustaka Pelajar,

(7) Ma'arif, Ahmad Syafi'i. Dunia Islam yang Melelahkan, di mana Al Qur'an? Suara Muhammadiyah, 2013, 17/98/ 1-15 Sept.

(8) Nata, AbudinPeta. Keragaman Pemikiran Islam di Indonesia. Jakarta: PT Raja Grafindo Persada, 2001
(9) Puspitasari, Elis, dkk., 2011, Penguatan Image Pesantren sebagai Lembaga Pendidikan Anti Teroris Melalaui Pencanangan Website. HUMANIS, Jurnal Sosial Ekonomi Humaniora LPPM Unsoed, 2011, Vol.5 (1).

(10) Patmanthara, Syaad. Pembelajaran melalui Internet Di Perguruan Tinggi. Jurnal Teknodik Pusat Teknologi Informasi Dan Komunikasi Pendidikan, Depdiknas, 2007, XI (20)

(11) Rohman, Abdul, dan Elis Puspitasari. Hukum

Toleransi Kelompok Salafi terhadap Kelompok Islam Lainnya di Kab. Banyumas. Jurnal DINAMIKA HUKUMFak. Hukum Univ. Juenderal Soedirman, 2011, Vol. 11 (3)

(12) Rohman, Abdul. Persepsi Kelompok Syahadatain Terhadap Interaksi Sosial Di Kabupaten Banyumas. Laporan Kajian Unsoed Purwokerto, 2008

(13) Rohman, Abdul. Persepsi Kelompok Islam Jama'ah Terhadap Interaksi Sosial Di Kec. Purwokerto Selatan Banyumas, Laporan Kajian Unsoed Purwokerto, 2009

(14) Suwarno, Peter, 2005, Resolving Religious Conflict Trough Expanding Inter-Religious Communication : Issues and Challenges.Al Jami'ah, Journal of Islamic Studies IAIN Sunan Kalijaga, Vol. 43 (2)

(15) Warsita, Bambang. Peranan Teknologi Informasi dan Komunikasi dalam Penyelenggaraan Pendidikan Jarak Jauh, dalamJurnal Teknodik Pusat Teknologi Informasi Dan Komunikasi Pendidikan, Depdiknas, 2007. 